\section{Evaluación del trabajo de grado No los mire, de la estudiante Paula Náñez}

La estudiante Paula Náñez presenta un trabajo compuesto por dos partes: primera, una bitácora en la cual expon el proceso de gestación y desarrollo de su proyecto; y, segunda, una producción escrita de carácter ficcional. En el trabajo de la estudiante Náñez resulta evidente la apuesta por la dimensión estética del lenguaje y, con fundamento en su investigación, por la construcción de memoria y el reconocimiento a tres mujeres que han padecido el rigor de la guerra que se libra en el país.

Para empezar, considero valiosa la experiencia que la estudiante Náñez ha tenido durante su investigación. A juzgar por lo dicho en la bitácora, desde la selección del tema y el objeto de estudio hasta la puesta en escritura final, la estudiante enfrentó diversas situaciones inesperadas y sobre la marcha tomó decisiones que le permitieron culminar el proceso con un producto de calidad. Ejemplo de ello fue el cambio de su idea inicial: la intención de realizar un documental acerca de cómo ven algunas mujeres desplazadas por la guerra la representación que dan los informativos de televisión sobre la situación de ellas, debió ser reconsiderada por el hecho palmario de que esas mujeres, las que dan vida a los personajes de No los mire, no tienen televisor. Igualmente sucede con alguno recursos que la estudiante Náñez empleó para poder conocer ese mundo sobre el cual se propuso escribir: as como ella quería conocer las historias de vida de Adiela, Lucía y Cristina, Paula compartió con ellas su propia a. De esta manera, la estudiante supo resolver es la fase de escritura — y sus soluciones repercutieron en la consistencia del trabajo.

En cuanto a su contenido, el trabajo se propone construir una ficción que dé cuenta de la atmósfera de miedo e incertidumbre que la guerra instaura en la cotidianidad. Su material de base es el relato de estas tres mujeres sobre lo que eran sus vidas antes de huir de los lugares donde residían. La atención, pues, no está puesta en el éxodo, sino en cómo los guerreros de uno y otro bando derruyen con su presencia los mundos de estas mujeres. Sin duda, el texto consigue recrear esa atmósfera. Lo real, o sea el recuerdo de las experiencias de Adiela, Lucía y Cristina y la manera como la autora comprende ese recuerdo, nutren la ficción. $Y$ a su vez, la ficción nos devuelve imágenes para mirar ese pasado y parte de la historia de la guerra que se libra en Colombia.

Así, al alcanzar ese propósito, a mi modo de ver el texto consigue otros. En efecto, al crear tres personaje femeninos localizados en tres lugares diferentes — Guaviare; Alto El Rocío, en Tuluá; Lejanías, Meta - el texto logra configurar una imagen de la ubicuidad de la guerra y de cierto modo uniforme como el terror invade lo espacios privados, carcome la vida y doblega a las personas. Al mismo tiempo, el texto consigue representar algo que, aunque intuimos que existe, parece olvidado: un país rural y agrario, al cual observamos desde las ciudades, si es que lo hacemos, distanciado y ajeno. Por último, aunque podría agregar otros elementos, más que a tres mujeres el texto nos enfrenta a la situación de menores, hombres, familias y grups hut modificadas, sin posibilidad alguna de redención, por la guerra.
Los logros del trabajo se deben, a mi juicio, al nivel que alcanza la escritura. Una escritura cuidada, clara, contenida, de oraciones y párrafos cortos, que intercala el discurrir de un narrador externo con los relatos de los personajes principales. Aunque aquí, hay que decirlo, las voces casi siempre parecen la misma. La escritura, además, elude los signos de violencia explícita, las grandes peripecias. En cambio, apuesta por el detalle simbólico, por la imagen, por el tiempo gramatical del presente, por la pausa y por la conjunción de niveles cronológicos en el relato.

En mi opinión, si algunos de los rasgos anteriores son fuente de los méritos del trabajo, también lo son de algunos reparos que se pueden formular al texto. En efecto, considero que en algunos momentos la escritura se excede en los detalles, tiene pasajes en los que se hace innecesariamente prolija la descripción de objetos y lugares. El marcado acento visual del texto, en mi criterio, a veces entra en demasiados pormenores. Asimismo ocurre con la descripción de algunas actividades que ejecutan los personajes. Por momentos, el texto recuerda imágenes exasperantes de la objetualidad del Nouveau roman, y la cotidianidad que se quiere representar se torna inmóvil, reiterativa. Si bien, preciso, la mía es una interpretación entre otras posibles, por la intención perceptible en el texto no creo que se quiera lograr un efecto de exasperación. Considero que este rasgo de la escritura se podría depurar. Antes de la entrega final vendría bien una revisión que busque una mavor economía del lenguaje. Creo que el texto no perdería en significación y podría ganar en densidad e intensidad.

Finalmente, quiero destacar la capacidad de este texto para hacer mirar la guerra que vivimos con una perspectiva que toma distancia de los puntos de vista más convencionales. Si bien se nota un grado de identificación emociona de la autora con las personas que le proporcionaron el material base de su escrito, y es evidente la selección sólo de cierto tipo de momentos para componer la cotidianidad doméstica que es derruida por la atmósfera de la guerra, con todo y eso el texto consigue que el lector reflexione sobre los efectos de la violencia en la subjetividad y en las relaciones familiares, y sobre la destrucción por parte del terror de las rutinas y de algunos sueños sencillos, como los de cualquier ser humano $\mathrm{A}$ lo anterior agrego un claro esfuerzo por enmarcar el producto un cuidado concepto editorial, el cual, seguramente, se verá en su dimensión real en la entrega definitiva.

Con fundamento en lo expuesto, considero que con el trabajo No los mire la estudiante Paula Náñez cumple con méritos más que suficientes para optar al título de Comunicadora Social-Periodista. Por sus cualidades, el trabajo merece la calificación meritoria.

Atentamente,

Manuel Enrique Silva Rodríguez Profesor

Escuela de Comunicación Social Universidad del Valle 